Check for updates

London

Cite this as: BMJ2020;370:m2734 http://dx.doi.org/10.1136/bmj.m2734 Published: 08 July 2020

\section{Covid-19: MPs call on government to produce detailed plans for PPE in England}

\author{
Jacqui Wise
}

The government is failing to act with "sufficient urgency" in building up stocks of personal protective equipment (PPE) in England ahead of a potential second wave of covid-19, the parliamentary public spending watchdog has warned.

The Public Accounts Committee said in a report that it was "extremely concerned" by widely reported shortages of PPE faced by NHS and care workers during the covid-19 pandemic and that it was vital to prevent the same problems from happening again. ${ }^{1}$ MPs said they were not convinced that the current procurement process was robust enough and called on the government to produce clear plans about how to distribute equipment, particularly in the more fragmented care sector.

Meg Hillier, the committee chair, said, "The government conducted a large pandemic practice exercise in 2016 but failed to prepare. The previous committee warned on the lack of plans to ensure access to medicines and equipment in the social care sector in the event of a no deal Brexit, but, again, the government failed to prepare.

"There must be total focus now on where the problems were in procurement and supply in the first wave, and on eradicating them."

The committee has called on the government to produce a detailed plan within two months outlining when it expects to have a predictable supply of stock and ready access to PPE supply in the NHS and care sectors. This should include details of who is responsible for the procurement and distribution of PPE across NHS and social care settings.

\section{Blaming}

The report comes soon after the prime minister, Boris Johnson, seemed to blame the owners of care homes for the high death toll from coronavirus in their properties. "Too many care homes didn't really follow the procedures in the way that they could have," he said on 6 July in Goole.

Almost 30 ooo more care home residents in England and Wales died from 28 December 2019 to 12 June 2020 than during the same period a year earlier, latest figures from the Office for National Statistics showed. Of these deaths, 19394 involved covid-19. ${ }^{2}$

Mark Adams, head of the charity Community Integrated Care, told BBC Radio 4's Today programme on 7 July that Johnson's comments were appalling. "I think we're almost entering a Kafkaesque alternative reality where the government sets the rules, we follow them, they don't like the results, they then deny setting the rules and blame the people that were trying to do their best," said Adams.

He added that the social care system had had to source $90 \%$ of PPE itself since the crisis began. He said that staff and residents in social care had not been routinely tested for covid-19 until the end of May and, although this was now happening, they were crying out for weekly or twice weekly testing.

Vic Rayner, executive director of the National Care Forum, said that the prime minister's comments were neither accurate nor welcome. She said, "Government guidance has come to the sector in stops and starts-with organisations grappling with over 100 pieces of additional guidance in the same number of days, much of which was not accompanied by an understanding of the operational implications of operating care services."

The Public Accounts Committee had heard evidence from the Department of Health and Social Care that, before the coronavirus pandemic, national purchasing of PPE was about $35-40 \%$ of the total, with other purchasing done regionally or locally. The department had gone from supplying 240 trusts to trying to supply 50 ooo customers in the health and social care sectors. Before the pandemic the department did not have a role in supplying PPE to private social care providers, said officials, and coordinating with so many different organisations was an enormous challenge.

House of Commons Public Accounts Committee. NHS capital expenditure and financial management. 8 Jul 2020. https:/publications.parliament.uk/pa/cm5801/cmselect/cmpubacc/344/34402.htm.

2 Office for National Statistics. Deaths involving covid-19 in the care sector, England and Wales. 3 Jul 2020. https://www.ons.gov.uk/peoplepopulationandcommunity/birthsdeathsandmarriages/deaths/articles/deathsinvolvingcovid19inthecaresectorenglandandwales/deathsoccurringupto12june2020andregisteredupto20june2020provisional.

This article is made freely available for use in accordance with BMJ's website terms and conditions for the duration of the covid-19 pandemic or until otherwise determined by BMJ. You may use, download and print the article for any lawful, non-commercial purpose (including text and data mining) provided that all copyright notices and trade marks are retained. 